\title{
ANALISIS KUALITAS PELAYANAN DALAM MENINGKATKAN KEPUASAN PENGGUNA JASA BARBERSHOP DI KECAMATAN SINGAPARNA KABUPATEN TASIKMALAYA
}

\author{
Agus Ahmad Nasrulloh ${ }^{1}$, Ikhsanul Fadillah ${ }^{2}$ \\ 1Program Studi Ekonomi Syariah, agusahmad@unsil.ac.id \\ ${ }^{2}$ Program Studi Ekonomi Syariah, ikhsanulfadillah17@gmail.com
}

\begin{abstract}
Barbershop business in Tasikmalaya District is increasingly prevalent, including in Singaparna District, but not all Barbershop in Singaparna District are visited by consumers. Competition between Barbershop is found in excellent service quality for consumers, the application of a quality service affects the development of customer satisfaction. The research method used is descriptive method with a qualitative approach. Data is obtained through direct interviews with owners of barbershop and consumers. Then the data is analyzed through the stages of data reduction or simplification, data presentation / presentation (Data Display), and drawing conclusions. The results showed that the quality of services provided in five Barbershop in Singaparna Subdistrict, Tasikmalaya Regency was quite good, this can be seen from the efforts made such as prioritizing appearance, neatly arranged facilities, tools that are always ready to use and choosing a strategic place. The reliability and responsiveness of barbershop can be seen from the consumer's assessment of indicators of reliability, responsiveness, empathy and assurance from Barbershop which is quite good.
\end{abstract}

Keyword : Quality of Sevice, consumer satisfaction, Barbershop

\begin{abstract}
ABSTRAK
Usaha barbershop merupakan bisnis yang menjanjikan, karena kebutuhan akan jasa pangkas rambut atau Barbershop semakin meningkat. Usaha Barbershop di Kabupaten Tasikmalaya sendiri semakin marak termasuk di Kecamatan Singaparna, namun tidak semua Barbershop di Kecamatan Singaparna banyak dikunjungi oleh konsumen. Persaingan antar Barbershop terdapat pada kualitas layanan prima bagi konsumen, penerapan suatu jasa yang berkualitas mempengaruhi perkembangan kepuasan konsumen. Metode penelitian yang digunakan adalah metode deskriptif dengan pendekatan kualitatif. Data diperoleh melalui wawancara langsung kepada pemilik barbershop dan konsumen. Kemudian data dianalisis melalui tahapan Reduksi data atau penyederhanaan, Paparan/sajian data (Data Display), dan Penarikan kesimpulan. Kualitas pelayanan yang diberikan di lima Barbershop di Kecamatan Singaparna Kabupaten Tasikmalaya cukup baik, hal ini terlihat dari usaha yang dilakukan seperti mengutamakan penampilan, sarana yang tertata rapih, alat-alat yang selalu siap pakai dan pemilihan tempat yang strategis. Kehandalan dan ketanggapan dari barbershop terlihat dari
\end{abstract}


penilaian konsumen terhadap indikator kehandalan, ketanggapan, empati dan jaminan dari Barbershop yang cukup baik. Kualitas pelayanan dalam meningkatkan kepuasan pengguna jasa Barbershop menurut persepektif Islam di Kecamatan Singaparna Kabupaten Tasikmalaya masih rendah, hal ini terlihat dari masih adanya Barbershop yang melayani model rambut Qaza', potong rambut perempuan dan tidak mengetahui model potong rambut yang boleh dan tidak boleh menurut Islam.

Keyword : Kualitas Pelayanan, Kepuasan Konsumen, Babershop

\section{PENDAHULUAN}

Usaha Barbershop merupakan bisnis yang menjanjikan, karena kebutuhan akan jasa pangkas rambut atau Barbershop semakin meningkat. Usaha Barbershop di Indonesia memiliki peluang yang sangat baik, terbukti dengan berdirinya puluhan atau bahkan ratusan Barbershop yang tersebar di seluruh penjuru tanah air. Potong rambut merupakan kebutuhan orang setiap bulannya, tak terkecuali bagi pria, dalam memenuhi kebutuhan tersebut bermunculan jasa potong rambut yang menawarkan layanan potong rambut hingga perawatan rambut khusus pria.

Para owner bersaing untuk dapat mencapai kepuasan konsumen yang akhirnya dapat berimbas pada terbentuknya word-of-mouth pada usaha mereka sendiri. Dengan adanya persaingan yang ketat tersebut maka pemilik usaha dituntut untuk dapat memberikan pelayanan, fasilitas, maupun harga yang sesuai untuk pelayanan yang diberikan nantinya (Sofian Assauri, 2015).

Para owner bersaing untuk dapat mencapai kepuasan konsumen yang akhirnya dapat berimbas pada terbentuknya word-of-mouth pada usaha mereka sendiri. Dengan adanya persaingan yang ketat tersebut maka pemilik usaha dituntut untuk dapat memberikan pelayanan, fasilitas, maupun harga yang sesuai untuk pelayanan yang diberikan nantinya (Sofian Assauri, 2015).

Usaha Barbershop di Kabupaten Tasikmalaya sendiri semakin marak dengan banyaknya Barbershop baru yang berdiri dan tersebar di wilayah Tasikmalaya termasuk di Kecamatan Singaparna, namun tidak semua Barbershop di Kecamatan Singaparna banyak dikunjungi oleh konsumen, karena hanya Barbershop tertentu yang terlihat ramai pengunjung. Menurut Husein Umar (2013),sikap konsumen dan minat untuk memakai pelayanan jasa dipengaruhi beberapa hal seperti harga, lokasi, promosi, dan pelayanan. Kualitas pelayanan yang diberikan harus dijaga untuk dapat bertahan dalam persaingan yang ketat. Hal tersebut mutlak dilakukan oleh pemilik usaha yang sedang dikelola. Jika sebuah usaha ingin bertahan hidup di persaingan yang ketat, maka harus memikirkan cara yang efektif agar dapat bersaing. Salah satu cara adalah dengan meningkatkan kualitas pelayanan yang maksimal tanpa konsumen merasa dibebani oleh harga pelayanan jasa tersebut. Bagi perusahaan yang memiliki orientasi mendapatkan keuntungan yang semakin besar, perubahan kombinasi harga dan kualitas secara inceremental sering dianggap tidak cukup memadai, oleh karena itu, mereka memilik kecenderungan meningkatkan kualitas dan sekaligus menurunkan harga. (Suwarsono Muhammad, 2013). 
Selain meningkatkan kualitas pelayanan, bagi usaha Barbershop dapat melakukan upaya lain seperti dalam sarana misalnya penataan ruangan interior maupun kelengkapan peralatan cukur. Dalam hal pelayanan pun, Barbershop berbeda dengan pangkas rambut biasa dari proses cukur rambut, cuci rambut, pijat kepala, sampai proses hairstyling atau penataan rambut ditawarkan oleh Barbershop yang tentunya tidak dijumpai pada pangkas rambut biasa. Pasti dengan adanya perbedaan tersebut para pelaku usaha Barbershop berani menawarkan harga yang berbeda dengan harga yang ditawarkan oleh pangkas rambut, tak heran jika Barbershop merupakan pilihan utama para pria yang memiliki status sosial menengah keatas.

Hasil studi yang dilakukan melalui wawancara pada pemilik barbershop pada bualan Februari 2018 diperoleh data bahwa usaha Barbershop di wilayah Kecamatan Singaparna sebanyak 30 buah. Kemudian dari hasil observasi penulis dan wawancara kepada 3 orang pemilik Barbershop didapatkan informasi bahwa dalam sehari rata-rata pelanggan yang melakukan cukur rambut sebanyak 15-20 orang (Elka, Deon). Responden mengatakan bahwa selama ini persaingan semakin ketat, banyaknya bermunculan usaha di wilayah Singaparna membuat pelanggan beralih ke tempat lain. Dari adanya hal ini responden mengaku kondisi demikian mengurangi pendapatannya. Untuk meningkatkan kualitas pelayanan, responden berpendapat telah melakukan upaya-upaya seperti memodifikasi lingkungan.

Selanjutnya wawancara juga dilakukan kepada 15 orang pelanggan dari ketiga Barbershop yakni Barbershop Elka, Barbershop Deon, Barbershop Mandiri masing-masing 5 orang. Dari hasil wawancara kepada 15 orang tersebut terkait dengan sarana, pelayanan dan kepuasan dapat dilihat pada tabel berikut:

\section{Tabel 1}

Penilaian pengguna jasa terhadap sarana, pelayanan dan kepuasan

\begin{tabular}{|c|c|c|c|c|c|c|}
\hline \multirow[t]{2}{*}{ Barbershop } & \multicolumn{2}{|r|}{ Sarana } & \multicolumn{2}{|c|}{ Pelayanan } & \multicolumn{2}{|c|}{ Kepuasan } \\
\hline & Baik & Tidak & Baik & Tidak & Puas & Tidak \\
\hline Elka & 4 & 1 & 4 & 1 & 3 & 2 \\
\hline Deon & 4 & 1 & 3 & 2 & 3 & 2 \\
\hline Mandiri & 2 & 3 & 3 & 2 & 2 & 3 \\
\hline
\end{tabular}

Sarana yang tersedia di Barbershop seperti sarana parkir yang cukup aman, papan plang nama Barbershop yang mudah dibaca, alat untuk cuci rambut, kain penutup badan yang bersih, televisi dan kipas angin yang tertata dengan rapih. Pelayanan yang diberikan seperti, perawatan wajah maupun cat rambut, pijat dan cuci rambut. Selanjutnya mengenai kepuasan didapatkan bahwa responden menilai keberadaan sarana atau bukti langsung (tangible) yang bersih, aman dan nyaman akan menarik minat konsumen untuk melakukan kunjungan ulang dalam menggunakan Barbershop tersebut. Konsumen berpendapat bahwa pelayanan di Barbershop ramah, selalu menyapa pada pelanggan, menanyakan kebutuhan, menawarkan bantuan, menawarkan minuman. Konsumen juga menilai kemampuan dalam potong rambut dinilai profesional, pelanggan merasa diperhatikan dan merasa akrab dengan penyedia pelayanan. 
Pengguna jasa Barbershop Elka didapatkan informasi mengenai sarana bahwa sebanyak 4 orang menilai sarana yang dimiliki Barbershop tersebut baik, sebanyak 4 orang menilai pelayanan baik dan sebanyak 3 orang merasa puas. Pengguna jasa Barbershop Deon sebanyak 4 orang mengatakan sarana yang ada termasuk baik, sebanyak 3 orang pelayanan yang baik dan sebanyak 3 orang merasa puas. Sedangkan pengguna Barbershop Mandiri sebanyak 2 orang mengatakan sarana yang ada termasuk baik dan 3 orang mengatakan pelayanan baik, sebanyak 2 orang merasa puas. Melihat dari hasil wawancara tersebut diperoleh tingkat kepuasan pengguna jasa Barbershop paling rendah adalah di Barbershop Mandiri.

Berdasarkan hasil wawancara dengan pengelola Barbershop diperoleh informasi bahwa seiring dengan diadakan perubahan baik perubahan tempat, fasilitas, pelayanan dan jenis jasa yang diberikan lebih banyak, maka jumlah konsumen dalam dua bulan terakhir cukup meningkat.

Tabel 2.

Perkembangan Konsumen

\begin{tabular}{|c|c|c|}
\hline Barbershop & $\begin{array}{c}\text { Jumlah } \\
\text { konsumen Sebelum }\end{array}$ & $\begin{array}{c}\text { Jumlah } \\
\text { konsumen sesudah }\end{array}$ \\
\hline Elka & 13 & 18 \\
\hline Deon & 17 & 23 \\
\hline Mandiri & 15 & 21 \\
\hline Rata-rata & $\mathbf{1 5}$ & $\mathbf{2 0}$ \\
\hline
\end{tabular}

Rata-rata perhari konsumen yang berkunjung mencapai 15 orang, namun saat setelah perubahan tersebut jumlah kunjungan konsumen meningkat dengan rata-rata 20 orang per hari. Kenyataan ini berbalik dengan apa yang mereka (Pemilik Barbershop) harapkan, Para pemilik Barbershop berharap setelah terjadinya peningkatan pelayanan di berbagai sisi dapat meningkatkan jumlah pengunjung 2 kali lipat atau lebih dari pada sebelumnya.

Beberapa penelitian terkait pengaruh pelayanan terhadap kepuasan telah dilakukan oleh Khariza, dalam penelitiannya menemukan hasil analisis deskriptif sebesar $81,2 \%$ untuk variabel reliability, 76,05\% variabel responsiveness, 81,8\% variabel assurance, 55\% variabel empathy, dan $80,2 \%$ variabel tangible. Serta $77,4 \%$ untuk variabel kepuasan konsumen. Secara parsial variabel reliability, responsiveness, dan tangible berpengaruh secara signifikan terhadap kepuasan konsumen, sedangkan variabel assurance dan empathy tidak berpengaruh secara signifikan terhadap kepuasan konsumen. Untuk secara simultan hasilnya variabel kualitas pelayanan berpengaruh sebesar $44,5 \%$ terhadap kepuasan konsumen (Khariza, Ferlina, Trenggana, 2015).

Berasal dari fenomena tersebut, maka muncul dugaan bahwa tidak semua Barbershop di Singaparna banyak dikunjungi konsumen. Hal ini sebagai dasar untuk melakukan strategi dalam meningkatkan kualitas pelayanan dan kepuasan pelanggan. Namun, tidak semua Barbershop khususnya di kecamatan singaparna dalam praktek terhindar dari apa yang di larang oleh Allah 
dan Rasulnya yang mana Islam memberikan batasan terhadap pelayanan khususnya dalam usaha Barbershop agar memperhatikan nilai-nilai Islam

\section{LITERATUR REVIEW}

\section{Kualitas Pelayanan}

Kualitas merupakan faktor kunci yang membawa keberhasilan usaha, pertumbuhan dan peningkatan posisi bersaing. Kualitas suatu produk diartikan sebagai derajat atau tingkatan dimana produk atau jasa tersebut mampu memuaskan keinginan dari konsumen. Dengan demikian kualitas menjadi faktor dasar keputusan konsumen untuk membeli suatu produ atau jasa (Nanang Fattah, 2015).

Kualitas pelayanan adalah bagaimana perusahaan secara utuh memberikan kinerja yang terbaik mulai dari aspek teknologi, informasi, kemudahan memperoleh dan menggunakan produk serta nilai lebih (Purwanto, 2010).

\section{Dimensi Kualitas Pelayanan}

Menurut A-Arif (2004), dimensi kualitas pelayanan di singkat dengan TERRA yaitu diantaranya adalah:

\section{Bukti langsung}

Tangible meliputi kelengkapan alat yang digunakan untuk melayani konsumen, alat dalam keadaan baik (siap dipakai) dan bersih, sehingga apabila sewaktu-waktu dapat digunakan. Penampilan ruangan dan alat yang ada didalamnya memberikan dampak pada kepuasan konsumen, karena penampilan fisik petugas adalah dimensi yang paling mudah dilihat pertama kali.

\section{Kehandalan}

Pengetahuan, sikap dan ketrampilan petugas merupakan kunci utama dalam memberikan pelayanan pada konsumen. Petugas secara terus menerus mengembangkan dirinya untuk dapat memberikan pelayanan yang efektif dan efisien, melalui peningkatan pendidikan yang berkelanjutan dan pengalaman yang diperoleh di instansi.

Di dalam hadist-hadist mulia, Rasulullah SAW telah mempraktikkan dan memerintahkan supaya setiap muslim senantiasa menjaga amanah yang diberikan kepadanya. Karena profesionalitas beliau pada waktu berniaga maupun aktifitas kehidupan yang lainnya, maka beliau dipercaya oleh semua orang dan mendapatkan gelar Al-Amin.

\section{Ketanggapan}

Daya tanggap merupakan keinginan atau kesediaan pemberi pelayanan untuk memberikan pelayanan tepat waktu. Responsiveness (daya tanggap), yaitu kemauan atau keinginan petugas untuk membantu dan memberikan jasa yang dibutuhkan konsumen. Membiarkan konsumen menunggu, terutama tanpa alasan yang jelas akan menimbulkan kesan 
negative yang tidak seharusnya terjadi. Kecuali apabila kesalahan ini ditanggapi dengan cepat, maka bisa menjadi sesuatu yang berkesan dan menjadi pengalaman yang menyenangkan.

Apabila perusahaan tidak bisa menepati komitmen dalam memberikan pelayanan yang baik, maka resiko yang akan terjadi akan ditinggalkan oleh pelanggan. Lebih dari itu, Allah Swt telah berfirman dalam QS.Al-Maidah: 1:

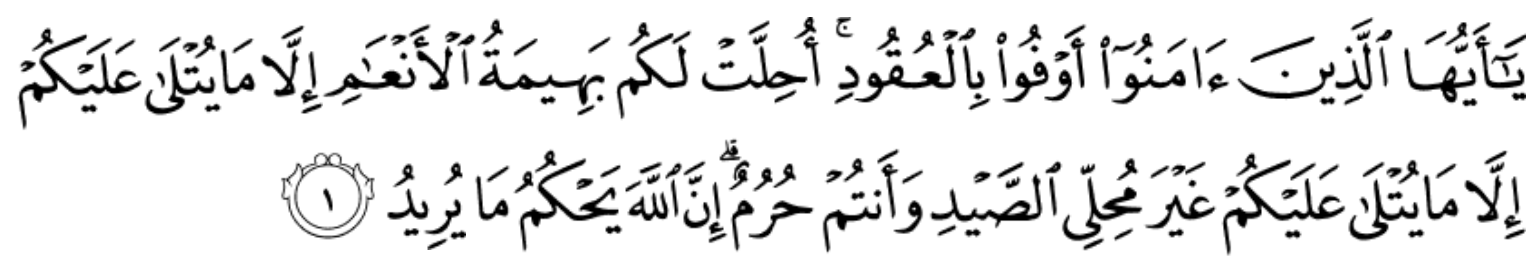

"Hai orang-orang yang beriman, penuhilah aqad-aqad itu. Dihalalkan bagimu binatang ternak, kecuali yang akan dibacakan kepadamu (Yang demikian itu) dengan tidak menghalalkan berburu ketika kamu sedang mengerjakan haji. Sesungguhnya Allah menetapkan hukum-hukum menurut yang dikehendaki-Nya".

\section{Empati}

Empathy yaitu memberikan perhatian yang tulus dan bersifat individual atau pribadi yang diberikan kepada konsumen dengan berupaya memahami keinginan pelanggan. Dimana suatu instansi diharapkan memiliki pengetahuan dan pengertian tentang kendaraan secara spesifik.

Perhatian yang diberikan oleh perusahaan kepada konsumen haruslah dilandasi dengan aspek keimanan dalam rangka mengikuti seruan Allah SWT untuk selalu berbuat baik kepada orang lain. Allah telah berfirman dalam QS. An-Nahl : 90:

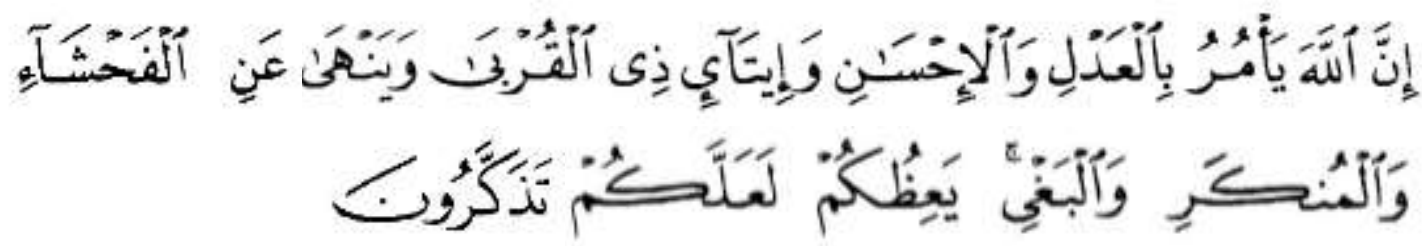

Artinya "Sesungguhnya Allah menyuruh (kamu) berlaku adil dan berbuat kebajikan, memberi kepada kaum kerabat, dan Allah melarang dari perbuatan keji, kemungkaran dan permusuhan. Dia memberi pengajaran kepadamu agar kamu dapat mengambil pelajaran."

\section{Jaminan pelayanan}

Jaminan yaitu pengetahuan, kesopan santunan dan kemampuan para petugas menumbuhkan rasa percaya para konsumen. Hal ini meliputi beberapa komponen antara lain komunikasi (communication), kredibilitas (credibility), keamanan (security), kompetensi (competence), dan sopan santun (courtesy).

Sehingga perusahaan tetap mendapatkan kepercayaan dari konsumen, dan yang terpenting adalah tidak melanggar syariat dalam bermuamalah. Allah SWT telah mengingatkan tentang etika berdagang sebagaimana yang termaktub dalam Q.S Asy-Syu'araa':181:

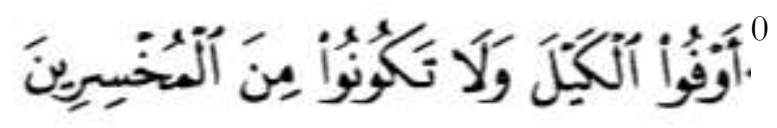


"Sempurnakanlah takaran dan janganlah kamu merugikan orang lain; dan timbanglah dengan timbangan yang benar".

Berdasarkan perspektif kualitas, dimensi kualitas ke dalam delapan dimensi yang dapat digunakan sebagai dasar perencanaan strategis terutama bagi perusahaan atau manufaktur yang menghasilkan barang dan jasa. Kedelapan dimensi tersebut adalah sebagai berikut (Murdifin Haming, 2014):

\section{Performance (kinerja),}

Kesesuaian produk dengan fungsi utama produk itu sendiri atau karakteristik operasi dari suatu produk.

\section{Features,}

Ciri khas produk yang membedak an dari produk lain yang merupakan karakteristik pelengkap dan mampu menimbulkan kesan yang baik bagi pelanggan.

\section{Reliability (kehandalan)}

Kepercayaan pelanggan terhadap produk karena kehandalannya atau karena kem ungkinan kerusakan yang rendah.

\section{Conformance (kesesuaian)}

Kesesuaian produk dengan syarat atau ukuran tertentu atau sejauh mana karakteristik desain dan operasi memenuhi standar yang telah ditetapkan.

\section{Durability (daya tahan)}

Tingkat ketahanan atau berapa lama produk dapat terus digunakan.

\section{Serviceability}

Meliputi kecepatan, kompetensi, kenyamanan, kemudahan dalam pemeliharaan dan penanganan keluhan yang memuaskan.

\section{Estetika}

Keindahan menyangkut corak, rasa dan daya tarik produk.

\section{Perceived}

Fanatisme konsumen menyangkut citra dan reputasi produk serta tanggung jawab perusahaan terhadapnya.

Berdasarkan uraian diatas, kualitas pelayanan memang bersifat abstrak dan subjektif tergantung dengan penerima layanan, namun dengan indikator kualitas pelayanan dapat diketahui dengan lebih akurat kualitas pelayanan publik yang ada.

\section{Kepuasan Pelanggan}

Kepuasan pelanggan sebagai hasil dari penilaian terhadap apa yang diharapkan dalam membeli dan mengkonsumsi produk atau jasa. Menurut Philip Kotler dalam M, Nur Rianto Al Arif mengatakan bahwa yang dimaksud kepuasan adalah kepuasan merupakan tingkat perasaan 
dimana seseorang menyatakan hasil perbandingan antara hasil kerja produk/jasa yang diterima dengan apa yang diharapkan (M. Nur Rianto Al Arif, 2004).

Kepuasan konsumen merupakan tingkat perasaan konsumen setelah membandingkan apa yang dia terima dan harapannya. Seorang pelanggan jika merasa puas dengan nilai yang diberikan sangat besar kemungkinan menjadi poelanggan dalam jangka waktu yang lama, sedangkan ketidakpuasan merupakan kesenjangan antara harapan dengan kenyataan layanan yang diterima oleh konsumen (Husein Umar, 2000).

\section{METODE}

\section{Metode Penelitian}

Metode penelitian dapat diartikan sebagai cara ilmiah untuk mendapatkan data yang valid dengan tujuan dapat ditemukan, dikembangkan, dan dibuktikan. suatu pengetahuan tertentu sehingga pada gilirannya dapat digunakan untuk memahami, memecahkan dan mengantisipasi masalah dalam bidang bisnis (Sugiyono, 2013).

Pada penenitian ini, metode penelitian yang digunakan adalah metode deskriptif dengan pendekatan kualitatif yaitu "suatu prosedur penelitian yang menghasilkan data deskriptif berupa tulisan dan perilaku yang dapat diamati dari obyek itu sendiri".

\section{Jenis dan Sumber Data}

Data dalam penelitian ini adalah semua data dan informasi yang diperoleh dari konsumen di lima Barbershop yang ada di Kecamatan Singaparna Kabupaten Tasikmalaya yang dianggap paling mengetahui secara rinci dan jelas mengenai fokus penelitian yang diteliti, yaitu kualitas pelayanan di lima Barbershop yang ada di Kecamatan Singaparna Kabupaten Tasikmalaya baik data primer maupun data sekunder. Selain itu diperoleh dari hasil dokumentasi yang menunjang terhadap data yang berbentuk kata-kata tertulis maupun tindakan.

\section{Teknik Pengumpulan Data}

Pengambilan sampel sumber data dilakukan secara purposive (sengaja) dan snowbaal (semakin bertambah), teknik pengumpulan dengan trianggulasi (gabungan) sumber, melalui wawancara, observasi, kuesioner/ angket serta dokumentasi. Analisis data bersifat induktif/kualitatif, dan hasil penelitian kualitatif lebih menekankan makna daripada generalitas (Sugiyono, 2013).

\section{Validitas dan Kredibilitas}

Validitas merupakan derajat ketepatan antar data yang sesungguhnya terjadi pada objek penellitian dengan data yang dapat dilaporkan oleh peneliti. Didalam uji validitas terdapat dua macam validitas penelitian, yaitu validitas internal dan validitas eksternal (Sugiyono, 2013).

Dalam pengujian keabsahan data, metode penelitian kualitatif menggunakan istilah yang berbeda dengan penelitian kuantitatif. Didalam penelitian kualitatif keabsahan data meliputi: Credibility (Validitas Internal) : perpanjangan pengamatan, peningkatan ketekunan, dan triangulasi : triangulasi sumber (Sugiyono, 2013). 


\section{Langkah Analisis Data}

Analisis data merupakan salah satu langkah penting dalam rangka memperoleh temuantemuan hasil penelitian. Teknik analisis data yang dipergunakan dalam penelitian ini adalah teknik deskriptif dengan membuat gambaran yang dilakukan dengan cara (1) Reduksi data atau penyederhanaan (Data Reduction), (2) Paparan/sajian data (Data Display), dan (3) Penarikan kesimpulan (Sugiyono, 2013).

\section{HASIL DAN PEMBAHASAN}

Penelitian ini dilakukan melalui wawancara kepada 5 orang informan sebagai pemilik Barbershop di wilayah Singaparna Kabupaten Tasikmalaya yaitu Barbershop Deon, Elka, Gebhoe, Mandiri dan Sukses serta 5 orang dari masing-masing pelanggan. Selain wawancara, data juga dilengkapi dengan data observasi yang diperkuat dengan dokumentasi berupa photo dan arsip yang ada. Adapun deskripsi dari masing-masing informan dapat dilihat pada tabel berikut:

Tabel 4.1

Karakteristik Informan

\begin{tabular}{|c|l|l|}
\hline Nama Inisial & \multicolumn{1}{|c|}{ Barbershop } & \multicolumn{1}{c|}{ Berdiri } \\
\hline I & Elka & 5 tahun \\
\hline Y & Deon & 3 tahun \\
\hline R & Mandiri & 5 tahun \\
\hline J & Sukses & 5 tahun \\
\hline AMS & Gebhoe & 7 tahun \\
\hline
\end{tabular}

Selain wawancara kepada pemilik barbershop, juga dilakukan pada konsumen dari masing-masing barbershop sebanyak 2 orang. Yaitu inisal AH dan IS sebagai konsumen barbershop Elka yang pernah memanfaatkan jasa cukur rambut Elka sebanyak 2 kali.

Konsumen berinisal $\mathrm{Z}$ dan KL sebagai konsumen barbershop Deon yang pernah memanfaatkan jasa cukur rambut Deon masing-masing sebanyak 2 kali dan 3 kali. Konsumen berinisal $\mathbf{J}$ dan DD sebagai konsumen barbershop mandiri yang pernah memanfaatkan jasa cukur rambut Deon masing-masing sebanyak 2 kali. Konsumen berinisal A dan AM sebagai konsumen barbershop Sukses yang pernah memanfaatkan jasa cukur rambut Sukses masingmasing sebanyak 2 kali. Serta terakhir konsumen berinisal I dan Y sebagai konsumen barbershop Gebhoe yang pernah memanfaatkan jasa cukur rambut Gebhoe masing-masing sebanyak 1 kali dan 3 kali.

Dalam semua pembicaraan wawancara mendalam, informan terbuka membicarakan masalah pelayanan, sarana dan kepuasan pelanggan sehingga dapat menjawab dan melakukan wawancara dengan lancar. Berikut hasil wawancara tersebut:

\section{Bukti Langsung}

Berdasarkan hasil penelitian melalui wawancara mengenai sarana/bukti langsung yang dimiliki oleh informan dalam pelayanan kepada konsumen. Dari hasil wawacara didapatkan 
sarana yang dimiliki oleh Barbershop berbeda-beda namun memiliki tujuan yang sama untuk meningkatkan pelayanan kepada konsumen. Berikut ini hasil wawancara saat ditanyakan mengenai indikator kualitas pelayanan :

- Mengutamakan penampilan, agar tampak rapih dan profesional karena tuntutan kerjadan penampilan mudah dilihat serta dinilai oleh konsumen

- Fasilitas- fasilitas yang tersedia untuk pelayanan konsumen Barbershop seperti alat cukur, ruang tunggu, parker ada yang sudah lengkap da nada juga yang belum, sehingga ada sebgian konsumen yang masih belum merasa puasa terhadap kualitas pelayanan beberapa barbershop.

- Cara perawatan pada sarana dilakukan sebelum dan sesudah digunakan agar senantiasa steril ketika akan digunakan

- Sarana dapat memenuhi kebutuhan konsumen: alat-alat cukur masih bagus dan bersih serta layak digunakan. Konsumen menilai pihak menyedia jasa ini memiliki sikap profesionalisme.

- Mensiasati agar sarana dan fasilitas di Barbershop dapat memenuhi kebutuhan konsumen, agar konsumen senantiasa merasa puas

- Pemilihan tempat agar mudah dijangkau oleh konsumen, seperti daerah perumahan, perkempungan yang memiliki padat penduduk, pusat kota.

\section{Kehandalan}

- Kemampuan dalam cukur rambut diperoleh kursus atau otodidak, konsumen menilai kemampaun dalam cukur rambut cukup lahai, bagus dan rapih serta menghasilkan kinerja yang memuaskan.

- Mengikuti trend model rambut, asal trend tersebut diketahuinya yang diketahui melalui media social, teman atau dari pelanggan sendiri.

- Permintaan konsumen senantiasa dapat dipenuhi termasuk dalam model rambut.

Menurut analisis peneliti, pemilik Barbershop yang memiliki perilaku profesional akan bertindak sesuai dengan keahliannya dan didukung oleh pengetahuan dan pengalaman serta keterampilan yang tinggi serta tidak melakukan tindakan coba-coba yang tidak didukung oleh pengetahuan dan profesinya.

\section{Ketanggapan}

- Lama waktu rata-rata yang dibutuhkan untuk mengerjakan satu jenis model 10-20 menit, dan konsumen tidak merasa lama menunggu proses pengerjaan atau menunggu giliran.

- Antrian konsumen yang mengaruskan konsumen menunggu lama. Hal ini biasanya terjadi pada momen-moment tertentu seperti hari libur sekolah atau menjelang hari raya.

- Cara mensiasatinya agar konsumen tersebut tidak merasa jenuh

Upaya pemilik barbershop dalam mengatasi rasa jenus konsumen yang menunggu giliran cukur rambu tersebut yaitu dengan menyediakan musik, televisi dan koran. Biasanya dengan memanfaatkan fasilitas tersebut konsumen dapat menikmati fasilitas yang disediakan. Konsumen Barbershop di lima Barbershop Singaparna sebagian merasa puas atas kemampuan pemilik Barbershop dalam memenuhi kebuttuhan dan keinginan konsumen. Hasil wawancara 
menunjukkan bahwa responden merasa puas terhadap kecepatan personil Barbershop dalam memberikan pelayanan pada konsumen Barbershop, selalu memberikan kesempatan untuk mengungkapkan keinginannya konsumen Barbershop, personil Barbershop memperhatikan atau menanyakan keluhan konsumen, personil Barbershop yang mudah untuk dihubungi saat dibutuhkan serta sebelum atau sesudah dilakukan pelayanan.

\section{Empati}

- Bersedia melayani konsumen yang meminta model rambut. Penyedia jasa selalu bersedia dalam memenuhi permintaan pelanggan.

- Keahlian dapat memenuhi keinginan pelanggan; Terkait dengan masalah kepuasan konsumen yang diperoleh dari hasil wawancara dengan konsumen barbershop diperoleh informasi konsumen menilai pihak barbershop dapat memahami kebutuhan dari konsumen. Konsumen mengatakan, selain hanya memahami tersebut juga pihak barbershop melakukan tindakan dengan cepat melayani keinginan dari konsumen.

- Mengutamakan kesopanan dan ramah terhadap semua konsumen, supaya menarik konsumen, merasa nyaman sehingga konsumen dapat datang kembali memanfaatkan usaha jasa cukur rambut tersebut.

- Mengajak berkomunikasi dengan konsumen. Hal ini menunjukkan bahwa pemilik barbershop memberikan kemudahan dalam komunikasi verbal untuk meningkatkan hubungan sosial dengan konsumen.

- Memperhatikan masalah yang sifatnya pribadi dengan konsumen; Konsumen menilai pihak barbershop dapat memberikan perhatian terhadap keluhan dan kebutuhan seperti dengan mengajak bicara, sehingga konsumen menilai pihak berbarshop memiliki empati yang baik dan mengerti terhadap keinginan konsumen

- Sikap dalam menghadapi konsumen yang mengalami keluhan dihadapi dengan sabar. Misalnya keluhan dalam hasil cukur rambut yang kurang sesuai dengan keinginan konsumen. Respon dari keluhan tersebut pemilik barbershop yaitu dengan menjelaskan keluhan konsumen, memperhatikan dan mengikuti keinginannya.

\section{Asuransi}

- Cara dapat menepati waktu dan janji dengan konsumen; Janji pemilik barbershop dengan konsumen biasanya dalam hal waktu untuk mendapatkan giliran, misalnya sedang sibuk mencukur rambut, istirahat dulu untuk makan, atau memberikan giliran pada waktu buka di hari berikutnya.

- Cara meyakinkan konsumen dalam hal keahlian dalam cukur rambut; Terkait dengan cara meyakinkan konsumen dalam hal kealian mencukur rambut didapatkan informasi bahwa untuk meyakinkan konsumen tidak bisa dengan penjelasan atau kata-kata.

Terkait dengan masalah kepuasan konsumen yang diperoleh dari hasil wawancara dengan konsumen barbershop diperoleh informasi bahwa konsumen menyatakan pemilik barbershop dan kemampuannya dalam potong rambut cukup baik, mislanya responden dapat melihat dari hasil pekerjaan, tampak profeional, berpengalaman dan terlatih. 
- Cara meyakinkan konsumen bahwa berpengalaman dalam cukur rambut; Terkait dengan profesionalisme dalam mencukur rambut, didapatkan informasi bahwa sebanyak tiga informan meyakinkan dengan cara menampilkan hasil pekerjaan dan sebanyak dua informan meyakinkan dengan menceritakan pengaman-pengalaman sebelumnya.

- Jujur mengatakan pada konsumen tentang hal penguasaan cukur rambut, apabila ditanya oleh konsumen.

- Membangun kepercayaan konsumen pada Barbershop; Sikap yang ditampilkan oleh pemilik barbershop, konsumen menilai ramah, baik dan murah senyum. Hal ini mengindikasikan bahwa pemilik barbershop menampilkan pelayanan, memperhatikan etika dalam usaha bahwa berhadapan dalam pelanggan menampilkan sikap yang dapat membuat nyaman.

- Terbuka pada konsumen mengenai pengetahuan dan keahlian yang dimiliki; Hasil wawancara mengenai pengetahuan dan kehalian yang dimiliki didperoleh informasi bahwa informan secara terbuka mengatakan kepada konsumen, itupun apabila diminta atau ditanyakan oleh konsumen. Selain dengan ucapan, juga ditunjukkan dengan keterampilan cara kerja yang dimiliki.

- Tarif harga; Penetapan harga cukur rambut atau pelayanan jasa lainnya disesuaikan dengan harga dipasaran atau harga yang lumah, karena tidak ada patokan khusus dari paguyuban cukur rambut. Konsumen menilai harga yang diberikan sesuai dengan harga dipasaran.

- Konsumen yang menawar tarif yang telah ditetapkan; Hasil wawancara terkait dengan tawaran tarif diperoleh informasi bahwa selama buka usaha jasa barbershop terdapat konsumen yang menawar harga yang telah ditetapkan. Walaupun hal tersebut jarang terjadi, tapi pada umumnya informan pernah mengalaminya.

Berdasarkan uraian tersebut, peneliti berpendapat bahwa kepuasan dapat dirasakan oleh konsumen jika kepercayaan konsumen dapat terpenuhi, serta pemilik Barbershop dapat memenuhi atas janji-janji yang telah ditawarkan. artinya Secara keseluruhan dimensi mutu pelayanan Assurance mempunyai nilai kepuasan yang cukup baik, terutama pada hal sikap Barbershop yang selalu menanyakan keinginan model rambut.

\section{KESIMPULAN}

Kualitas pelayanan yang diberikan di lima Barbershop di Kecamatan Singaparna Kabupaten Tasikmalaya cukup baik, hal ini terlihat dari usaha yang dilakukan seperti mengutamakan penampilan, sarana yang tertata rapih, alat-alat yang selalu siap pakai dan pemilihan tempat yang strategis. Kehandalan dan ketanggapan dari barbershop terlihat dari penilaian konsumen terhadap indikator kehandalan, ketanggapan, empati dan jaminan dari Barbershop yang cukup baik, sehingga secara keseluruhan konsumen merasakan kepuasan terhadap kualitas pelayanan yang diberikan. 


\section{REFERENSI}

Assauri, Sofian. 2015. Manajemen Pemasaran: Dasar Konsep dan Strategi, Jakarta: Rajawali Pers

Departemen Agama RI, 2004. Al-Quran dan Terjemahannya. Cet. II. Jakarta: Depag

Fattah, Nanang. 2015. Manajemen Strategik Berbasis Nilai. Bandung: Remaja Rosdakarya.

Haming, Murdifin. 2014. Manajemen Produksi Modern. Jakarta: Bumi Aksara

Khariza, Vicky; Ferlina, Arlin; Trenggana, Mochamad. 2015. Pengaruh Kualitas Pelayanan Terhadap Kepuasan Konsumen Di Barbersop Bandung. E-Proceeding of Management: Vol.2, No.3

Poerwanto, 2010. Corporate Social Responsibility. Jakarta: Pustaka Pelajar.

Rianto Al Arif, MN. 2004. Dasar-Dasar pemasaran Bank Syariah. Bandung: Alfabeta

Sugiyono. 2013. Metode Penelitian Bisnis, Bandung, Alfabeta.

Suwarsono, Muhammad. 2013. Manajemen Strategik. Konsep dan alat Analis. Jogjakarta : STIM. YPKN

Umar, Husein 2013. Desain Penelitian Manajemen Strategik, Jakarta: Rajawali Pers 2000. Studi Kelayakan Bisnis. Jakarta: Gramedia Pustaka 